\title{
SUSTAINABLE BUSINESS
}

\section{DEVELOPMENT THROUGH LEADERSHIP IN SMES}

\author{
KATARZYNA SZCZEPAŃSKA-WOSZCZYNA, \\ JOANNA KUROWSKA-PYSZ
}

\begin{abstract}
A B S T R A C T
The aim of this paper is to examine the role and scope of the influence of leadership on the sustainable development of SMEs. Research methods included the theoretical analysis of scientific literature and a direct survey. The quantitative sample for analysis contained 138 managers, the representatives of companies (SMEs) located in Poland. The data was collected in November and December 2015.

The obtained results show that leadership is one of the key aspects that enable sustainability. It is more important than employee approval, beliefs of employees from individual departments and teams, a long-term strategy for the sustainable development of the company, approval by external stakeholders, and substantial financial resources. There is a statistically significant relationship between taking action related to sustainable business in the company and manager's conviction (awareness) regarding the concept of sustainable business development as well as the influence of the manager on employees and the stimulation of their behaviour, including their development, decent treatment, communication with the manager, and the system of rewards and promotions. Managers undertake some action aimed at developing their employees. They also establish relationships with external stakeholders.

The paper presents theoretical reflections on the relationship between the sustainable business development of SMEs and leadership, also verified by the empirical study conducted among managers of private companies. The findings of the study contribute to the understanding of the connections between these constructs. The relationship between the creation of sustainable business development is analysed in depth with reference to SMEs. Entrepreneurs and managers of SMEs can benefit from the study in order to build an organisation capable of achieving effective and sustainable development.
\end{abstract}

KEY WORDS

sustainable development, sustainable business, corporate sustainability, small and medium-sized enterprises, leadership

DOI: 10.1515/emj-2016-0024
Corresponding author:

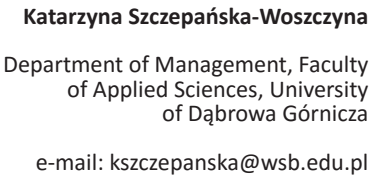

Joanna Kurowska-Pysz

Department of Production Management, Non-local Faculty in Cieszyn, University of Dabrowa Górnicza

e-mail: jkurowska@wsb.edu.pl

\section{INTRODUCTION}

Together with increasing social, environmental and economic challenges, which have already become a constant component of the social and economic environment of every organisation, it is thought that companies (businesses) play a key role in shifting the society towards a more sustainable future (BaumannPauly et al., 2013; Hall et al., 2010). The economies of both developed and developing countries are largely based on the activities of small and mediumsized enterprises (SMEs). The SMEs also play a significant role as far as sustainable development is concerned. The European Commission policies emphasize the fundamental role that SMEs play in the shift towards a new and more sustainable models of production and consumption that can be obtained 
by investments in human resources as well as social and environmental capital (Szczepańska-Woszczyna \& Lis, 2015). Not only are SMEs a source of economic growth, but also innovation in all industries. Besides, they provide jobs for the citizens of the countries concerned. They also offset the negative economic trends and support the restructuring of industries. The sustainable development of the sector is vital to the economy and is a prerequisite to achieving economic growth for at least a few reasons. Firstly, small and medium-sized enterprises create six out of ten workplaces. Secondly, SMEs are leaders in the industry transformation from traditional forms of production to advanced technologies. Thirdly, SMEs play an important role in developing innovation, whose aim is to improve their competitiveness. Organisations in this sector also contribute to the development of the global market. Innovation plays a significant role in enhancing the competitiveness of SMEs, which is conditioned by competencies, in particular, that of managers (Szczepańska-Woszczyna, 2014).

It is simultaneously estimated that SMEs may be jointly accountable for up to $70 \%$ of industrial pollution (Entr, 2004). Financial obstacles followed by a lack of time and qualified personnel have been identified as the most significant in the development and implementation of sustainable innovations (Vasilenko \& Arbačiauskas, 2012). SMEs have difficulties to integrate the environmental aspects into their activities (Bradford \& Fraser, 2008; Drake et al., 2004; Revell \& Blackburn, 2007) and environmental efforts made by SMEs are a matter of the owner's choice (De Gobbi, 2011; Nulkar, 2014). It seems that SMEs tend to be more reactive than proactive in the environmental field (De Gobbi, 2011). Several factors contribute to SMEs' lack of interest in sustainable development. Previous studies (De Gobbi, 2011; Gadenne et al., 2009; Gerstenfeld \& Roberts, 2000) indicate the major barriers, i.e. added costs and low awareness on the part of an owner, poor management skills and the lack of capacity to turn environmental improvements into business opportunities as well as the lack of skills to implement environmental improvements. Compliance itself comes at a cost and voluntary practices not resulting in direct business benefits may be ignored (Hobbs, 2000).

It is emphasized in the literature that the principles of sustainability are an indispensable part of the process of value creation: on the one hand, centralizing and combining ethical values and entrepreneurial values (Spence \& Lozano, 2000; Vyakarnam et al., 1997), on the other hand, the significance of the ability to establish relationships through participation in networks (Jabłoński, 2015; Kurowska-Pysz \& Gregor, 2014). The identification of instruments facilitating a sustainable business model in those companies represents a huge potential for the transfer towards a sustainable economy. As regards SMEs, the importance of interactions with society to the forefront is underlined. These interactions involve a company improving the relationships with actors of its value chain, with policy-makers, with researchers, with non-governmental organisations (NGOs), and with customers. For SMEs, success in sustainability depends on the extent of collaboration and the quality of these interactions (Cramer, 2006; Perrini \& Tencati, 2006; Waddock \& Bodwell, 2004). Companies fulfil a significant function in the society, not only as an entity that makes a profit but also as a provider of specific values anticipated by the society. These key values are most frequently defined in the company mission statement. It is a peculiar declaration of an organisation's identity, both for its employees and stakeholders outside the organisation. Managers are responsible for its effective enforcement by means of operating activities. Therefore, it is essential to translate the selected values into a set of competencies characterizing a given company (e.g. creativity, flexibility, customer orientation) as well as to inspire employees to follow the values. That is the leaders' task (Moszoro, 2012). Managers are especially responsible for integrating sustainability into company's strategy.

The literature on sustainability integrated into business practices has naturally focused on large, usually multinational companies, where impacts are significant (Bos-Brouwers, 2010; Epstein \& Buhovac, 2014; Laurinkevičiūtè \& Stasiškienè, 2010). Similarly, research on the sustainable value creation through leadership is conducted primarily in large organisations. Nevertheless, researchers claim that it is necessary to look at the development of SMEs in a different way than the development of large organisations (Hillary, 2000). The authors emphasize the gap and necessity to study sustainable behaviours in the SME sector, where unique approaches are required with specific leadership and understanding of the SME culture. Professionalization of management processes and the high level of competences are two of the most important requirements that modern organisations have to cope with (Drucker, 2004; Koźmiński, 2008; Nogalski 
\& Śniadecki, 2001), especially in the case of SMEs and their sustainable development. In SMEs, it varies in terms of a form and conditions (Jenkins, 2006; Stewart \& Gapp, 2011). According to Hambrick and Mason, SME leaders influence organisational outcomes (Hambrick \& Mason, 1984). This influence, as Hambrick and Mason claim, is mediated by the leaders' strategic choices that are driven by their values and cognitive bases. However, there has been little research on influence, and still little is known about the social practices of business related to the sustainability of SMEs. The literature on SMEs and their practices in a sustainability context is not extensive (Jansen, 2008) and the area requires further investigation. Due to this gap, the aim of the paper is to examine the role and scope of the influence of leadership on the sustainable development of SMEs. The study aimed to identify the key aspects of leadership that enable sustainability. It becomes increasingly important to understand what successful SME leaders do and how they behave to influence the sustainability of their companies. Therefore, three hypotheses were formulated for the purpose of research: Hypothesis 1. Leadership is one of the key factors that enable sustainability. Hypothesis 2. Own values of the managers are a key determinant of their activities and decisions taken related to sustainable development of a company. Hypothesis 3. Stimulation of employee awareness and development as well as their responsibility for the environment by owners/managers positively affect sustainable business development in SMEs.

The research was conducted in two stages. The first stage was a pilot study conducted in January and February 2015 on a group of 91 private sector organisations. The aim of the pilot study was to test the assumptions for real research. The paper presents the results of the real research (the second stage), conducted in November and December 2015 among 138 randomly selected companies (micro, small and medium-sized enterprises) implementing strategies for sustainable business development. The data for the research was collected on the basis of results of a questionnaire sent to the representatives of private organisations located in Poland.

\section{LITERATURE REVIEW}

The United Nations Brundtland Commission defines sustainable development as „development that satisfies the economic, environmental and social needs of the current generation without compromising the development of future generations" (Lacy et al., 2010). As regards companies, the concept of sustainable development assumes that when some actions are taken, social and ecological problems are taken into account, both related to the company and the relationship with its stakeholders (internal stakeholders: shareholders, employees and managers and external ones: customers, business partners and society), (Jabłoński, 2010). In this context, the company focuses on a sustainable increase and development and integrates economic criteria as well as social and environmental goals while managing its activity. Thus, it can be concluded that development contributes to economic prosperity and the quality of environment and social capital (Vincenza Ciasullo \& Troisi, 2013).

The concept of sustainability is understood as durability; sustainability is a relatively new concept, still not fully explored in the business world. Grudzewski et al. (2010) define sustainability as the company's ability to continuously learn, adapt and develop, revitalize, reconstruct, and reorient to maintain a lasting and distinctive position in the market by offering buyers above-average value today and in the future (consistent with the paradigm of innovative growth) through organic variation constituting business models, and arising from the creation of new opportunities, objectives and responses to them, while balancing the interests of different groups. Sustainable business development involves the application of sustainability principles to business operations. Sustainability in this sense may mean a variety of things - ecological sustainability, social sustainability or sustained economic growth. As such, the sustainable business movement is a component of the broader movement towards greater corporate social responsibility (Rainey, 2010). According to the Network for Business Sustainability, business sustainability is the inclusion of financial, environmental and social concerns in business decisions. Sustainable companies: 1) create a longterm financial value, 2) know how their actions affect the environment and actively work to reduce their impacts, 3) care about their employees, customers, and communities and work to make a positive social change, and 4) understand that these three elements are interconnected. Although there are several perspectives of defining „sustainability”, the essence is related to the organic development of the company in a dynamic equilibrium with its external business environment and natural environment. Sustainability 
implies vision and competitive advantage, which means strategic thinking and leadership (Bratianu, 2015).

The goal of a company is to create value together with society, the value which combines the development of society with the economic development (Porter \& Kramer, 2007). Every company should take decisions considering the common value. Such an approach offers greater innovation and continuous development, which will bring more benefits to the whole society. There are four key sustainable categories of values which should be included in the company's mission statement: (1) business - related to business activity and making a profit, e.g. perseverance, effectiveness, professionalism, and performance orientation; (2) rational - values related to the quality of interpersonal relationships, e.g. communication, teamwork, and respect for people; (3) developmental, such as innovation, creativity, learning or continuous development; and (4) related to the contribution for the benefit of others (e.g. actions in the area of CSR), (Cardona \& Rey, 2009). A company should be observed from the perspective of providing measurable benefits contributing to the creation of value for society (Martin et al., 2009). Hoag, Cooper (2006) highlight the multifaceted perception of values, which are the basis for interactive relationships between a company and its environment. One can thus talk about a group of values subject to the processes of exchange and that are the basis for considering reciprocal benefits for owners, customers, managers, employees, and other groups of stakeholders.

The long-term positive influence on the environment translates not only into image benefits for the company but also into financial ones. Companies are obliged to fulfil formal and legal requirements as well as to make an increased investment in human resources, environment, and relationships with stakeholders who can have a real impact on the efficiency of economic activities of these organisations and their innovation (expenditure of this kind should be regarded as an investment and a source of innovation rather than as an expense), (Szczepańska-Woszczyna et al., 2015). Strong leadership is of paramount importance for the sustainable development of a company, directly affecting the key areas of an organisation: the degree of the innovativeness of the company, its corporate reputation, its performance, financial stability and relationships with customers. The role of leadership responsible for the development and implementation of the company's brand strategy is crucial, although often underestimated. The awareness of managers as regards the fairness of activities is increasing (Sadecki, 2013). Doppelt argues that „for an organisation to make this kind of transformation to become truly sustainable, power and authority must be skilfully distributed amongst employees and stakeholders through effective information sharing, decision making and resource allocation mechanisms" (Doppelt, 2003). This is clearly an issue for the leaders of organisations. Supporting this view, Goehrig has emphasized the role of leadership in creating a sustainable and realistic business environment. $\mathrm{He}$ states that changing the business outcome requires changes to existing business structures. He highlights the need for executives, consultants, and management leaders to understand and implement new strategies (Goehrig, 2008). Also, in the research of SMEs conducted by Stewart and Gapp, a link between situational leadership and the successful uptake of CSR and sustainability has been found (Stewart \& Gapp, 2011). According to Hind and Smit, there is considerable evidence that the leadership role is critical to the implementation of any sustainability development (Hind et al., 2013). In addition to leadership, Benmeriphi lists other factors such as: (1) access to skilled labour, (2) access to financial resources through the banking system, (3) the ability to respond to market demands, (4) a flexible institutional framework as the main factors that determine sustainable business development in SMEs.

The company creates value when managers are sustainability-oriented. In particular, this concerns SMEs where the owner-manager takes the responsibility for main decisions. Driving factors for SMEs to engage in at least parts of sustainable development are often personal and ethical values of the company's owners, managers, and employees. Companies where organisation members have a personal interest in involving in environmental and social issues are likely to pay attention to social and environmental issues ((EC), 2007). The ownermanager of an SME is both the author (creator) and performer (the one who enforces) of some values. Managers express their own personal values through their behaviour, the ways of taking decisions, and articulated values (Hemingway \& Maclagan, 2004). The scale of business goals in the case of SMEs is linked with the owner-manager, for whom the relationship between personal and business success is 
much closer than in the case of delegating managerial competencies to other people, and takes the form of ethical and responsible behaviour regardless of the outcome. In this context, the feeling of belonging from the perspective of an entrepreneur and their feeling of being part of a community becomes a unique "springboard” to create conditions for sustainable development. Research on sustainable entrepreneurship proves how sustainable entrepreneurs reveal personal competency and consider their professional life as a creative act. Differences between personal goals and perceived reality are regarded as a challenge rather than a problem. Moreover, sustainable entrepreneurs greatly influence the company with their personal goals and preferences in such a way that these are reflected in the company's goals. Employees are expected to have such personal skills as ethics and loyalty; responsibility and commitment; self-reliance; openness to learning and continuous development; the ability to work under time pressure; correct selfesteem; flexibility and the ability to adapt; and empathy. This is more common in small companies rather than in larger enterprises (Ciasullo \& Troisi, 2011; Kurowska-Pysz, 2014).

Employees play an important role in the company's pursuit of sustainable business development policy and, therefore, the owner/manager should involve them in initiated sustainable activities. It is employees that are often the best and most effective channels of information. Employees should be aware of all the environmental and pro-social activities performed by the company because then they may contribute significantly to the effectiveness of these activities. Many companies have developed the ways of engaging employees in projects through joint actions and environmentally-friendly behaviour. Integrating corporate strategy, HR strategy and the strategy of sustainable development has a significant impact on the long-term financial performance of the company, the coherent development of employees and the organisation.

In the broader perspective, human capital, including the quality of managers (risk-taking tendency, entrepreneurship and commitment, the quality of marketing, technical and financial staff, and employees (qualifications, efficiency, and creativity) is listed as one of core components of the potential for company competitiveness, in addition to such components as: (2) physical and financial resources, (3) invisible resources - information, technologies, innovations, reputation, unique skills, informal liaisons, patents, licences, work atmosphere, organisational culture, experience, contacts, and (4) organisational resources (a decision-making system, distribution and logistics networks, organisational structure, connections with suppliers and consumers, etc.), (Skawińska, 2002). According to Subramaniam, Youndt (2005) and Ciasullo, Troisi (2011), the ability of an organisation to create sustainable value is directly related to the intellectual (human, structural, and relational) capital, and it makes it possible to analyse such factors as reliability, credibility, satisfaction, honesty, and relationships with stakeholders. Simultaneously, the analysis of separate components of intellectual capital explains the sources of creation of sustainable value at an individual level (person), the level of organisational structures, processes, systems, relationships, and networks. The competitive advantage of companies results from their characteristic management and organisational skills (the way of coordinating and using resources, developing products, creating alliances, etc.), and is shaped by positions of assets specific to the company (including know-how, the competitiveness of offered products and services, and delivering a measurable group of values to customers), as well as the development path(s) that the company has taken (Teece et al., 1997). To maintain the competitive advantage, an organisation must possess the ability („dynamic opportunity”) to adapt, integrate and reconfigure its internal and external organisational skills, resources and functional competencies so as to meet the requirements of the changing environment. According to Teece (2007), this dynamic ability depends, to a large extent, on the top-level management. To be able to successfully manage an organisation, managers „must act entrepreneurially, think strategically, and execute flawlessly" (Augier \& Teece, 2009), they must be leaders, articulate goals, help to assess opportunities, build trust and play a key role in taking decisions strategic for the organisation. It is estimated that companies may achieve much more profit (by $30 \%$ ) if managers apply practices that stimulate an increase in employee commitment and competencies (Cardona \& Rey, 2009).

It is the managers' role to promote the expected values, to specify the unacceptable behaviours and to enforce the appropriate attitudes of lower-level managers. Brand building and "healthy" corporate culture are the components of bilateral communication with all important partners as well as with employees. The image of the company and organisational culture 
that identify the company in a business environment through CSR activities, advertising campaigns or employer branding, must be reliable and consistent with the elements that the staff perceive and declare (Szczepańska-Woszczyna, 2015).

The role of managers is to create such conditions for the company's operation that the mission and values become one whole underlying structure of the organisational culture of the company. If the mission is the goal that determines the direction of activities, values become the criteria and guidelines in the process of taking decisions in the most suitable manner of conduct in a particular situation. Values show how to pursue the mission. A proper selection of values that are consistent with the mission is an important part of what Cardona and Rey (2009) refer to as „intrategy”, i.e. an increase in the employees' commitment to the company's affairs through managers' decisions, examining the environment of the company and internal processes occurring in it. The successful company will give its employees many opportunities to bear responsibility. It is increasingly necessary to decentralise decision making.

\section{RESEARCH METHODS}

Research methods were the theoretical analysis of scientific literature and a direct survey (questionnaires were the instrument of data collection). The quantitative sample for analysing contains the representatives of companies (SMEs) located in the Province of Silesia in Poland. The companies randomly selected in the sample are members of the regional chamber of commerce. The total of 300 enterprises was involved, including micro (up to 9 employees), small (10-50 employees) and medium-sized enterprises (51-250 employees). A total number of 138 correctly completed questionnaires were received (not all of the questionnaires were suitable for further analysis, the respondents who failed to answer at least 20 per cent of the questions were excluded). The survey was sample-based, and random sampling was applied. The data was collected in November and December 2015. The questionnaires were the instrument of data collection. The database contains 20 variables characterizing 138 managers/owners of SMEs. The variables were measured on the seven-point Likert scale, seven indicating "maximum agreement" and one meaning "no agreement”. In addition to demographic data, the questionnaire contained questions on the key elements of company's business sustainability, the manager's role in the company's sustainable development, attention paid to employees, establishing relationships with employees and external stakeholders, and the promotion of activities aimed at the sustainable use of raw materials and energy. The analysis was conducted at two levels: the statistical description in the sample and statistical inference involving the generalization of the results obtained in the sample of the statistical population. Basic tables with descriptive statistics were used for the statistical description, giving the idea of the tested material structure, including matrix categorized histograms, and box-and-whisker plots. In terms of statistical inference, non-parametric statistical tests were applied: (1) a Spearman's linear rank correlation coefficient to examine the existence of a statistical relationship between the variables, (2) the chi-square test of independence in order to examine the existence of a statistically significant relationship between two variables. In order to determine the strength of the relationship between the qualitative variables, the measure of relationship strength based on the Cramer's V chi-square was used; (3) descriptive and exploratory factor analysis aimed at isolating the natural groups of variables. All hypotheses were verified at a significance level of 0.05 . The analysis of the results also uses p-value, which is the smallest level of significance at which the null hypothesis can be rejected. Calculations were performed using Statistica 12.5.

Enterprises were of different size (employment criterion): micro-enterprises accounted for $31.2 \%$ of the respondents, small businesses - over $42.0 \%$, and medium $-26.8 \%$. The majority of respondents were male (63.3\%), between 31 and 40 years of age $(41.7 \%)$, with a mean of 12.73 years of experience as a manager.

\section{RESEARCH RESULTS}

\subsection{Leadership as one of the key aspects that enable sustainability}

In the research group, $65.2 \%$ of the respondents declared that a sustainable policy was fully pursued in their companies, and $55.0 \%$ of the respondents were personally involved in the company's sustainable policy. The factors determining the effective implementation of actions in the area of sustainable business that were rated highly include the 
dependence of the effective implementation of actions for sustainable development on the owner/ managers convinced of these activities. The box-andwhisker diagram shows the median and the diversity of the ratings of statements defining the effective action in the area of sustainable business (Fig. 1). were studied) does not determine the factors that the effective implementation of activities for sustainable development may depend on (the chi-square test of independence was used; Tab. 1). There is a statistically significant relationship between the size of the company and external stakeholder approval

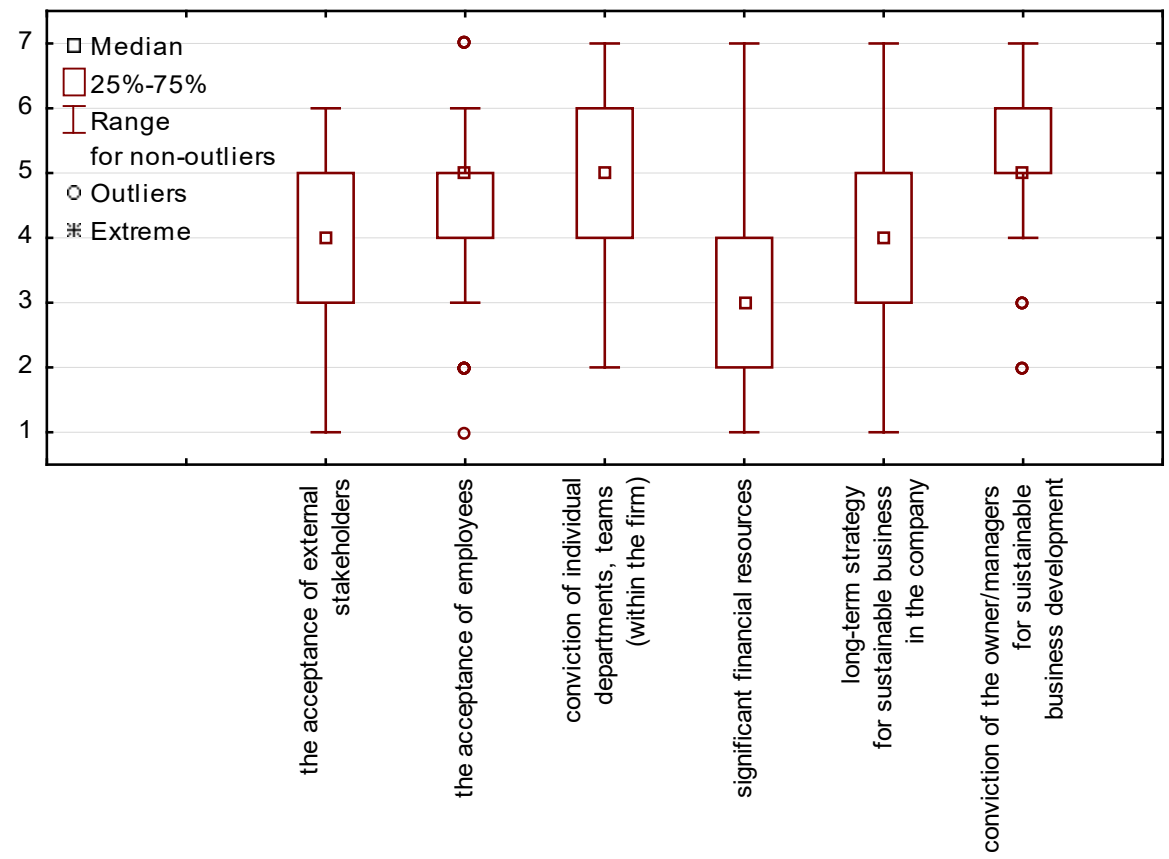

Fig. 1. Diversity of the ratings of statements defining the effective action in the area of sustainable business

Moreover, every second respondent rated this factor as a five (on a scale from one to seven). None of the respondents rated this factor as „I completely disagree”. Next, the following factors were rated highly: employee approval, the beliefs of employees from individual departments and teams, having a long-term strategy for sustainable development in the company, external stakeholders' approval, and finally, having substantial financial resources. The highest convergence of ratings was for the dependence of the effective implementation of activities for sustainable development on the owner/managers convinced of these activities and employee approval. The greatest diversity of ratings was for having substantial financial resources and having a longterm strategy for sustainable development in the company. If leadership means dependence of actions on owners/managers, it indicates that the statement is true.

The size of the company (the analysis was conducted for two groups of companies: small, micro and medium-sized $(75 \%$ of micro and small enterprises and $25 \%$ of medium-sized enterprises of such measures. This relationship, however, is poor (Cramer's coefficient $=0.23662$ ). Other relationships are statistically insignificant.

\subsection{The areas where SME managers have an impact on sustainability business development}

In order to test the influence that a manager has on business sustainability, the questions were selected from the survey expressing the opinions and position of managers in the field of sustainable development. Using the factor analysis, a group of determinants of the sustainable development of the company was identified based on the opinions of managers. The factor analysis allows the transformation of a mutually correlated set of variables into a new set of variables (so-called common factors) mutually uncorrelated, but comparable to the initial system. The advantage of factor analysis is an opportunity to discover the optimal number of hidden variables that explain the interrelationship between observed variables.

The basis for the contention that in the study there are groups of determinants of sustainable business 
Tab. 1. Relationship between activities in the area of sustainable business and the size of the company (the chi-square test of independence ( $p$-value))

\begin{tabular}{|c|c|c|c|c|c|}
\hline \multicolumn{7}{|c|}{ FACTOR VS. SIZE OF THE COMPANY (P-VALUE) } \\
\hline $\begin{array}{c}\text { External stake- } \\
\text { holders' approval }\end{array}$ & $\begin{array}{c}\text { Employee } \\
\text { approval }\end{array}$ & $\begin{array}{c}\text { Beliefs } \\
\text { of employees }\end{array}$ & $\begin{array}{c}\text { Financial } \\
\text { resources }\end{array}$ & $\begin{array}{c}\text { A long-term strategy } \\
\text { for sustainability }\end{array}$ & $\begin{array}{c}\text { Dependence } \\
\text { on owners / managers, }\end{array}$ \\
\hline $.01821^{*}$ & .69680 & .63223 & .54169 & .81035 & .14198 \\
\hline
\end{tabular}

* significance level of 0.05

development in the company is the correlation matrix, which proves the significant relationships between variables. The Kaiser-Meyer-Olkin Measure of Sampling Adequacy was determined for 16 variables, and the Barlett's test was performed. Both tests (KMO is greater than 0.6 and Barlett's test $\mathrm{p}=0.000$ ) indicate the validity of applying the factor analysis. The data was analysed in terms of principal components. Based on the analysis of the Eigen values and variance explained, 16 input variables were reduced to seven dimensions, explaining a total of $73.88 \%$ of the total variation.

Thus, sustainable business is evaluated at seven levels. Factors were defined as:

- (a) the attitude of a manager to the sustainable development of the company: the ability to identify and analyse potential aspects of sustainable development in business situations, the correct understanding of the idea of sustainable business by managers and employees, and manager's decisions and solutions reflect their personal values,

- (b) an influence the manager has on employees and stimulating their behaviour: the awareness that decisions taken by the manager have a strong influence on the behaviour of others, the request for the opinion of others before taking a decision, encouraging subordinates to express their own opinion, the awareness that the improper structure of incentives may lead to the unethical behaviour of employees,

- (c) the development and decent treatment of employees: effectiveness in supporting the development of employees, care for the health and safety of employees, and the decent treatment of employees as a standard in the company,

- (d) the communication of the manager with employees/environment: both business and ethical reasons for their opinion/decision are regularly explained,

- (e) the system of rewards and promotions based on an ethical attitude: the ethical attitude of employees is a component in the system of rewards and promotions in the company,

- (f) the manager's own contribution to sustainable development of the company: promoting activities aimed at reducing the consumption of raw materials and energy among employees; the manager's personal involvement in the company's operations in the field of sustainable business, it is important that the company I run/where I work takes action in the field of sustainable business,

- (g) manager's activities for the benefit of the external environment: a belief that every company should hire employees from the region, in which it operates and buy from local suppliers.

For these groups, correlations with other questions that show the actual state of the company were calculated: taking action for the benefit of the community, in which it operates, supporting it financially and non-financially, the company has a clear policy for contacts with stakeholders, the company has talent management programmes, the company has a clear promotion path for employees, and the company takes action in the field of sustainable business. Simultaneously, correlations with the group regarding the presence of activities related to sustainable business in the company and convincing the manager of the concept of sustainable business development were calculated (GROUP A). Personal involvement of the manager in the company's operations in the field of sustainable business; it is important to me that the company I run/where I work takes action in the field of sustainable business, my company takes action in the field of sustainable business, the manager's ability to identify and analyse the potential aspects of sustainable development in business situations, the correct understanding of the idea of sustainable business by managers and employees). The results are presented in Table 2.

There is a statistically significant relationship between taking action related to sustainable business in the company and manager's conviction (awareness) of the concept of sustainable business development and the influence of the manager on employees and stimulating their behaviour (factors (b), (c), (d), and (e)). Simultaneously, there is a significant moderate correlation between the influence of the manager on 
Tab. 2. Correlation of factors

\begin{tabular}{|c|c|c|c|c|c|c|c|}
\hline & \multicolumn{7}{|c|}{ VARIABLES VS ... (P VALUE) } \\
\hline & (a) & (b) & (c) & (d) & (e) & (f) & (g) \\
\hline Q.1 & - & $0,255770^{*}$ & 0.075725 & $0.284942^{*}$ & -0.017281 & 0.050422 & -0.033537 \\
\hline 0.2 & - & $0.334401 *$ & 0.071562 & $0.178462 *$ & 0.038406 & 0.032889 & 0.014249 \\
\hline 0.3 & 0.146387 & 0.053935 & $0.334356^{*}$ & 0.150264 & $0.294706^{*}$ & $0.327640 *$ & 0.132659 \\
\hline Q.4 & $0.234979 *$ & $0.373838 *$ & $0.211594^{*}$ & $0.352888^{*}$ & $0.304695^{*}$ & $0.174648 *$ & 0.034196 \\
\hline Q.5 & -0.018426 & $0.242307^{*}$ & $0.406066^{*}$ & $0.285513^{*}$ & $0.361544^{*}$ & $0.277581^{*}$ & $0.178168 *$ \\
\hline Q.6 & -0.050178 & 0.082939 & $0.508204^{*}$ & $0.218394 *$ & $0.265816^{*}$ & $0.420346 *$ & 0.153937 \\
\hline Q.7 & 0.137810 & $0.279363^{*}$ & $0.359196 *$ & 0.053346 & 0.088777 & 0.160614 & 0.154224 \\
\hline $\mathrm{Q} .8$ & -0.085329 & -0.060566 & $0.310791 *$ & 0.161568 & $0.339427^{*}$ & - & $0.168873 *$ \\
\hline 0.9 & -0.121605 & 0.112893 & $0.259666^{*}$ & 0.094649 & 0.136710 & - & $0.228885^{*}$ \\
\hline 0.10 & -0.083265 & -0.090056 & 0.110791 & -0.067367 & 0.018818 & $0.475802 *$ & 0.098125 \\
\hline GROUP A & - & $0.367638 *$ & $0.279428^{*}$ & $0.300831^{*}$ & $0.203413^{*}$ & - & 0.127987 \\
\hline 0.11 & 0.010852 & -0.160259 & 0.024740 & -0.027328 & -0.065386 & 0.109683 & 0.046868 \\
\hline
\end{tabular}

* (1) I am able to identify and analyse the potential aspects of sustainable development in business situations; (2) In order for a company to be socially responsible, its executives and employees must properly understand the idea of sustainable business; (3) My company takes action for the benefit of community in which it operates, supports it financially and non-financially; (4) The company has a clear policy for contacts with stakeholders; (5) The company has talent management programmes; (6) The company has a clear promotion path for employees; (7) My company is operating in the field of sustainable business; (8) I involve personally in the company's operations in the field of sustainable business; (9) It is important to me that the company I run / where I work takes action in the field of sustainable business; (10) Leadership should be regarded as an element aimed at managing the value for stakeholders; (11) The size of the company (micro, small, medium)

employees and stimulating their behaviour (factors (b), (c), (d), and (e)) and having a clear company policy for contacts with stakeholders and the development of talent management programmes in the company. There is also a statistically significant correlation between the manager's attitude to the of the impact their decisions as managers have on the behaviour of others, and $10.9 \%$ to a moderate extent. It is important to the respondents to take decisions that are consistent with their own values; in the long term, they can be effective only if these two areas converge. $63.1 \%$ of the respondents state that their

Tab. 3. Positional descriptive statistics for selected variables

\begin{tabular}{|l|c|c|c|c|c|c|c|}
\hline VARIABLE & MEdiAn & Mode & $\begin{array}{c}\text { NUMBER OF } \\
\text { MODES }\end{array}$ & Minimum & MAXIMUM & $\begin{array}{c}\mathbf{2 5} \\
\text { PERCENTILE }\end{array}$ & $\begin{array}{c}75 \\
\text { PERCENTILE }\end{array}$ \\
\hline Q.1 & 5 & 5 & 39 & 2 & 7 & 4 & 6 \\
\hline Q.3 & 5 & 5 & 44 & 1 & 7 & 4 & 6 \\
\hline Q.4 & 6 & 5 & 43 & 1 & 7 & 5 & 6 \\
\hline Q.6 & 4 & 5 & 36 & 2 & 7 & 3 & 5 \\
\hline
\end{tabular}

sustainable development of the company and a clear company policy for contacts with stakeholders.

The analysis of the issue of whether the action and decisions taken by a manager in the field of sustainable development are consistent with their own values indicates that the rating of at least half of the respondents in terms of individual variables (a, b, c, d) was 5 or 6 . The most frequent value (the mode) was the rating of 5 (scale $1-7$, where one is the lowest rating), (Tab. 3).

$\ldots 81.2 \%$ of the respondents are definitely aware decisions and solutions as managers fully reflect their personal values (their business decisions over the last five years), $22.5 \%$ - moderately, low convergence is declared by $14.4 \%$ of the respondents (median: 5 ).

\section{DISCUSSION OF THE RESULTS}

The paper presents theoretical reflections on the relationship between sustainable business 
development of SMEs and leadership, also verified by the empirical study conducted among managers of private companies. The findings of the study contribute to understanding the connections between these theoretical constructs. The findings are consistent with research that indicates that relationship.

The research findings indicate that leadership is identified as one of the key factors that determine the implementation of sustainable development. This is consistent with the conclusions drawn by De Gobbi (2011), Stewart and Gapp (2011), and Hind et al. (2013). Among factors determining the sustainable development of SMEs are the awareness and motivation of the owner or manager. The majority of managers understand the concept of sustainable business development, can identify the activities related to this concept, and implement single solutions. The study indicates that according to managers, sustainable development can be the key to the company's future success. Similar results were obtained in the study conducted by the United Nations Global Compact (Lacy et al., 2010). Managers want to be aware of the actions undertaken, it is important to them that the decisions they make are consistent with their own values. This is favourable to the effectiveness of managers' activities. Not only does the law define the standard for what is considered acceptable in business, but also broader expectations of the society. Furthermore, with contemporary fast pace business climate and transparency, poor judgments are seen immediately across the world. Consequently, leaders must take decisions that reflect not only traditional economic but also ethical considerations. As the CGMA report shows, in many SMEs the finance function plays a critical role in formulating and implementing a sustainability strategy (Ten key..., 2013). The obtained results indicate that having significant financial resources for sustainable development in the studied companies was less important than leadership, employee approval, beliefs of employees from individual departments and teams, having a long-term strategy for sustainable development in the company, and external stakeholders' approval.

The sustainable business includes the understanding of values and the satisfaction of managers, employees and customers (Grönroos, 2007; Waddock \& Bodwell, 2004). One should agree with the opinion of Hemingway and Maclagan (Hemingway \& Maclagan, 2004) and De Gobbi (2011), that the effectiveness of the action taken by owners/managers in the field of sustainable development requires their personal commitment and conviction. It is important to the owners/ managers to take decisions that are consistent with their own values. In the long term, they can be effective only if these two areas converge. The study shows that it is important for leaders to offer guidance to employees on behaviour-related expectations to make them responsible decision-makers. The challenge is to strike a balance between the needs of the organisation and the needs of its stakeholders and to establish the process of two-way communication with organisation stakeholders (Sroka \& Gajdzik, 2015). This is evidenced by research that managers' activities are focused on building the relationships with both internal and external stakeholders.

\section{CONCLUSIONS}

In Poland, the breakthrough moment in the introduction of the concept of sustainable development into the national legislation was the recognition of the concept of sustainable development as a constitutional principle in 1997. Since the turn of the 20th and 21st centuries, there has been an increase in the interest in the concept of sustainable business development in the activities of enterprises. In contrast to countries with about 30 years of experience in the implementation of the concept of sustainability, its Polish history is rather short. Summarizing the research findings, it can be concluded that the idea of sustainable business development in Polish SMEs is still in the development phase.

The quality of human resources and their advantage in an organisation are increasingly becoming the crucial factors of the growth. Consequently, the human resources occur to be the main asset of an organisation and often determine the competitive advantage of the organisation in the market. In the process of current activities and during the implementation of the long-term strategies, organisations search for new methods of maximal benefiting from the staff competences. In the broadest sense, any activities of an organisation are always based on competences of employed staff. Practical implications result from literature studies, but first of all, they refer to empirical research analyses findings presented in the paper. They involve the identification of instruments facilitating a sustainable 
business model in SMEs. Identification of factors influencing the growth of a sustainable business of SMEs has a crucial meaning because SMEs represent an enormous potential for the transfer towards a sustainable economy.

Managers of SMEs can become an important catalyst for changes in the way of thinking about the company's growth and development, and, consequently, the economic development. They play a special role in identifying the values of the company and in shaping its organisational culture, identifying key issues and creating the image of the company's future development. A significant condition of the practical implementation of the sustainable business development concept is, however, the managers' mental ability to perceive chances resulting from it and to persuade all the stakeholders to introduce necessary changes. In the processes of company's sustainable development, the leadership must be both competent and sincere. The behaviour and actions of a manager must include both personal and professional aspects. A manager needs to be authentic and reliable, and know how to positively balance various interests. Giving advice, they simultaneously include and inspire their colleagues to work well. They prevent situations in which employees have to deal with serious moral dilemmas by establishing clear ethical principles and in which employees are exposed to serious temptations. Not only does a real manager establish clear rules of conduct but they are also able to enforce them and solve problems that may arise.

\section{LITERATURE}

Augier, M., \& Teece, D. J. (2009). Dynamic capabilities and the role of managers in business strategy and economic performance. Organization Science, 20(2), 410-421.

Baumann-Pauly, D., Wickert, C., Spence, L. J., \& Scherer, A. G. (2013). Organizing corporate social responsibility in small and large firms: Size matters. Journal of Business Ethics, 115(4), 693-705.

Bos-Brouwers, H. E. J. (2010). Corporate sustainability and innovation in SMEs: evidence of themes and activities in practice. Business Strategy and the Environment, 19(7), 417-435.

Bradford, J., \& Fraser, E. D. (2008). Local authorities, climate change and small and medium enterprises: identifying effective policy instruments to reduce energy use and carbon emissions. Corporate Social Responsibility and Environmental Management, 15(3), 156-172.
Bratianu, C. (2015). Organizational Knowledge Dynamics: Managing Knowledge Creation, Acquisition, Sharing, and Transformation: Managing Knowledge Creation, Acquisition, Sharing, and Transformation. IGI Global.

Cardona, P., \& Rey, C. (2009). Zarządzanie przez misje [Management by mission]. Kraków, Poland: Wolters Kluwer Polska.

Ciasullo, M., \& Troisi, O. (2011). The creation of sustainable value in SMEs. A case study. Paper presented at the Conference Proceedings 14th Toulon-Verona Conference „Organizational Excellence in Services”, University of Alicante - University of Oviedo.

Cramer, J. (2006). Corporate Social Responsibility and Globalisation: an action plan for business: Sheffield, Great Britain: Greenleaf Publishing

De Gobbi, M. S. (2011). Mainstreaming Environmental issues in sustainable enterprises: An exploration of issues, experiences and options. Geneva, Switzerland: International Labour Office.

Doppelt, R. (2003). The seven sustainability blunders. The Systems Thinker, 14(5), 1-7.

Drake, F., Purvis, M., \& Hunt, J. (2004). Meeting the environmental challenge: a case of win-win or losewin? A study of the UK baking and refrigeration industries. Business Strategy and the Environment, 13(3), 172-186.

Drucker, P. F. (2004). Menedżer skuteczny [Effective manager]. Konstancin-Jeziorna, Poland: MT Biznes.

European Commission. (2007). Opportunity and Responsibility - How to help small business to integrate social and environmental issues into what they do. Directorate-general for enterprises and industry.

Entr, D. (2004). Public Policy Initiative to promote the Uptake of environmental Management Systems in small and medium-sized Enterprises. Final Report of the BEST Project Expert Group.

Epstein, M. J., \& Buhovac, A. R. (2014). Making sustainability work: Best practices in managing and measuring corporate social, environmental, and economic impacts. San Francisco, USA: BerrettKoehler Publishers.

Gadenne, D. L., Kennedy, J., \& McKeiver, C. (2009). An empirical study of environmental awareness and practices in SMEs. Journal of Business Ethics, 84(1), 45-63.

Gerstenfeld, A., Roberts, H. (2000). Size matters: barriers and prospects for environmental management in small and medium-sized enterprises. In R. Hillary (Ed.), Small and medium-sized enterprises and the environment: Business Imperatives (pp. 106-119). Sheffield, Great Britain: Greenleaf Publishing.

Goehrig, R. (2008). The role of leadership in building high performing, sustainable organizations. Government Finance Review, 24(6), 6-14.

Grönroos, C. (2007). Service management and marketing: customer management in service competition. John Wiley \& Sons.

Grudzewski, W., Hejduk, I., Sankowska, A., \& Wańtuchowicz, M. (2010). Sustainability $w$ biznesie, czyli przedsiębiorstwo przyszłości - zmiany paradygmatów $i$ koncepcji zarzadzania [Sustainability in business, enterprise of the future - change management concepts 
and paradigms]. Warszawa, Poland: Poltext.

Hall, J. K., Daneke, G. A., \& Lenox, M. J. (2010). Sustainable development and entrepreneurship: Past contributions and future directions. Journal of Business Venturing, 25(5), 439-448.

Hambrick, D. C., \& Mason, P. A. (1984). Upper echelons: The organization as a reflection of its top managers. Academy of management review, 9(2), 193-206.

Hemingway, C. A., \& Maclagan, P. W. (2004). Managers' personal values as drivers of corporate social responsibility. Journal of Business Ethics, 50(1), 33-44.

Hillary, R. (2000). Small and medium-sized enterprises and the environment: business imperatives. Sheffield, Great Britain: Greenleaf Publishing.

Hind, P., Smit, A., \& Page, N. (2013). Enabling sustainability through an action research process of organisational development. Journal of Corporate Citizenship, 49, 137-161.

Hoag, B., \& Cooper, C. L. (2006). Managing value-based organizations: it's not what you think. Northampton, Great Britain: Edward Elgar Publishing.

Hobbs, J. (2000). Promoting Cleaner Production in SMEs. In R. Hilary (Ed.), SMEs and the Environment (pp. 149-157). Sheffield, Great Britain: Greenleaf Publishing.

Jabłoński, A. (2010). A sustainable development and sustainable business in creation of value the companies responsible socially. Zeszyty Naukowe Wyższej Szkoły Humanitas. Zarzadzanie, 2, 15-30.

Jabłoński, A. (2015). Network dynamics and business model dynamics in improving a company's performance. International Journal of Economics, III(1), 1-10.

Jansen, J. J. (2008). Combining competence building and leveraging: managing paradoxes in ambidextrous organizations. Advances in Applied Business Strategy, 10(10), 99-119.

Jenkins, H. (2006). Small business champions for corporate social responsibility. Journal of Business Ethics, 67(3), 241-256.

Koźmiński, A. K. (2008). Koniec świata menedżerów [End of the world of managers]. Warszawa, Poland: Wydawnictwo Akademickie i Profesjonalne.

Kurowska-Pysz, J. (2014). Development of student's professional competences within the framework of science-business cooperation. Polish Journal of Management Studies, 9, 115-126.

Kurowska-Pysz, J., \& Gregor, M. (2014). The transfer of knowledge in technological cross-border industry cluster-case study. Management Systems in Production Engineering, 2(14), 63-67.

Lacy, P., Cooper, T., Hayward, R., \& Neuberger, L. (2010). A new era of sustainability. UN Global Compact, Accenture.

Laurinkevičiūtè, A., \& Stasiškienė, Ž. (2010). Sustainable development decision-making model for small and medium enterprises. Environmental Research, Engineering and Management, 52(2), 14-24.

Martin, J. D., Petty, J. W., \& Wallace, J. S. (2009). Value based management with corporate social responsibility. New York, USA: Oxford University Press.
Moszoro, B. (2012). Znaczenie misji przedsiębiorstwa i jej wpływ na kompetencje przywódcze [The importance of enterprise mission and its impact on leadership competencies]. Management and Business Administration. Central Europe, 2(115), 53-62.

Nogalski, B., \& Śniadecki, J. (2001). Umiejętności menedżerskie $w$ zarzadzaniu przedsiębiorstwem [Managerial skills in business management]. Bydgoszcz, Poland: Oficyna Wydawnicza Ośrodka Postępu Organizacyjnego.

Nulkar, G. (2014). Does environmental sustainability matter to small and medium enterprises? Empirical evidence from India. International Journal of Environmental Studies, 71(4), 481-489.

Perrini, F., \& Tencati, A. (2006). Sustainability and stakeholder management: the need for new corporate performance evaluation and reporting systems. Business Strategy and the Environment, 15(5), 296308.

Porter, M. E., \& Kramer, M. R. (2007). Strategy and Society: The Link between Competitive Advantage and Corporate Social Responsibility. Harvard Business Review, 84(12), 78-92.

Rainey, D. L. (2010). Sustainable business development: inventing the future through strategy, innovation, and leadership. Cambridge, USA: Cambridge University Press.

Revell, A., \& Blackburn, R. (2007). The business case for sustainability? An examination of small firms in the UK's construction and restaurant sectors. Business Strategy and the Environment, 16(6), 404-420.

Sadecki, B. (2013). Społeczna odpowiedzialność przedsiębiorstw korzystna w biznesie [Corporate social responsibility favorable business]. Wprost, 13, 86-87.

Skawińska, E. (2002). Konkurencyjność przedsiębiorstw: nowe podejście [Competitiveness: a new approach]. Warszawa-Poznań, Poland: Wydawnictwo Naukowe PWN.

Spence, L. J., \& Lozano, J. F. (2000). Communicating About Ethics with Small Firms: Experiences From the U.K. and Spain. Journal of Business Ethics, 27(1-2), 43-53.

Sroka, W., \& Gajdzik, B. (2015). Managerial Challenges for Networks and Beyond (pp. 121-134). W. Sroka \& Š. Hittmár (Eds.), Management of Network Organizations: Switzerland: Springer International Publishing.

Stewart, H. J., \& Gapp, R. (2011). Situating leadership to develop CSR sustainable practices within an SME context. In T. Clark (Ed.), Presented at the 25th Annual Conference of the British Academy of Management Conference (BAM2011), Birmingham, United Kingdom.

Subramaniam, M., \& Youndt, M. A. (2005). The influence of intellectual capital on the types of innovative capabilities. Academy of Management Journal, 48(3), 450-463.

Szczepańska-Woszczyna, K. (2014). SMEs managers a need for competence. Acta Technologica Dubnicae, $4(1), 1-16$ 
Szczepańska-Woszczyna, K. (2015). Leadership and organizational culture as the normative influence of top management on employee's behaviour in the innovation process. Procedia Economics and Finance, 34, 396-402.

Szczepańska-Woszczyna, K., Dacko-Pikiewicz, Z., \& Lis, M. (2015). Responsible leadership: a real need or transient curiosity. Procedia - Social and Behavioral Sciences, 213, 546-551.

Szczepańska-Woszczyna, K., \& Lis, M. (2015). Evaluating innovation activities in small and medium enterprises. In J. Kaczmarek, \& P. Krzemiński (Eds.), Development, innovation and business potential in view of economic changes. Cracow, Poland: Cracow University of Economics.

Teece, D. J. (2007). Explicating dynamic capabilities: the nature and microfoundations of (sustainable) enterprise performance. Strategic Management Journal, 28(13), 1319-1350.

Teece, D. J., Pisano, G., \& Shuen, A. (1997). Dynamic capabilities and strategic management. Strategic Management Journal, 18(7), 509-533.

Ten key elements to sustainable business practices in SMEs. (2013). Retrieved from http://www.cgma.org

Vasilenko, L., \& Arbačiauskas, V. (2012). Obstacles and drivers for sustainable innovation development and implementation in small and medium sized enterprises. Environmental Research, Engineering and Management, 60(2), 58-66.

Vincenza Ciasullo, M., \& Troisi, O. (2013). Sustainable value creation in SMEs: A case study. The TQM Journal, 25(1), 44-61.

Vyakarnam, S., Bailey, A., Myers, A., \& Burnett, D. (1997). Towards an understanding of ethical behaviour in small firms. Journal of Business Ethics, 16(15), 16251636.

Waddock, S., \& Bodwell, C. (2004). Managing responsibility: what can be learned from the quality movement? California Management Review, 47(1), 25-37. 